\title{
P02-020 - CAPS in Turkish children: treatment with ANTI IL1
}

\author{
FK Kara Eroglü, N Besbas, F Ozaltin, Y Bilginer, A Duzova, S Ozen \\ From 7th Congress of International Society of Systemic Auto-Inflammatory Diseases (ISSAID) \\ Lausanne, Switerland. 22-26 May 2013
}

\section{Introduction}

Criyopyrin associated periodic syndrome (CAPS) has a heterogenous presentation and in a number patients mutations can not be found. Here we present our initial results with CAPS patients.

\section{Case Report \\ Results}

All of our patients had symptoms within the first 3 months of life. All had fever, urticaria and persistant labaratory inflammation. All except one patient had failure to thrive. Except for the one patient with Muckle Wells syndrome all had neurological features ranging from headache to convulsions, hydrocephalus, cognitive dysfunction. Two patients, one without a mutation, had hearing impairment. Two patients have diarrhea during attacks. All were started on anti IL1, one patient who did not respond to anakinra was started to canakinumab and on the fourth dose he developed MAS. After MAS was subsided canakinumab was re-started and he continues the drug without further problems. Presently three patients are on anakinra and three are on canakinumab, all with normal acute phases and improved quality of life. One patient has associated Duchenne muscular dystrophy.

\section{Discussion}

\section{Conclusions}

Anti IL1 treatment is efficacious in CAPS patients. Somatic mutations may enlighten the mutation negative patients. Until then classification criteria are needed to guide pediatricians in diagnosis and treatment.

\section{Disclosure of interest}

None declared.

$$
\text { Pediatric Rheumatology Department, Hacettepe University Faculty of }
$$$$
\text { Medicine, Ankara, Turkey }
$$

Published: 8 November 2013

\section{Reference}

1. Sibley Cailin H, Plass Nikki, Snow Joseph, et al: Sustained Response and Prevention of Damage Progression in Patients With Neonatal-Onset Multisystem Inflammatory Disease Treated With Anakinra. A Cohort Study to Determine Three- and Five-Year Outcomes. ARTHRITIS \& RHEUMATISM 2012, 64(7):2375-2386.

doi:10.1186/1546-0096-11-S1-A127

Cite this article as: Eroglu et al.: P02-020 - CAPS in Turkish children: treatment with ANTI IL1. Pediatric Rheumatology 2013 11(Suppl 1):A127.
Submit your next manuscript to BioMed Central and take full advantage of:

- Convenient online submission

- Thorough peer review

- No space constraints or color figure charges

- Immediate publication on acceptance

- Inclusion in PubMed, CAS, Scopus and Google Scholar

- Research which is freely available for redistribution
C Biomed Central 